\title{
Effect of Petroleum Hydrocarbons on Microbial Populations in an Arctic Lake
}

\author{
M. J. JORDAN, J. E. HOBBIE and B. J. PETERSON
}

\begin{abstract}
A sea-curtain enclosed section of a lake $240 \mathrm{~km}$ south of Prudhoe Bay, Alaska was exposed to Prudhoe crude oil in July 1976. One year following exposure to the oil, no significant differences were detected between the waters or sediments of the oiled versus control area in rates of turnover of glucose. Total numbers of bacteria were slightly higher in oiled than in control waters. There were no differences in numbers of sediment bacteria.

Rates of uptake of hexadecane and napthalene by sediment microbes were not linear with time. Hexadecane was taken up sooner and faster than was napthalene. In some incubations, significantly ( $88-95 \%$ probability level) greater rates of hydrocarbon uptake were measured for oiled than for control sediments. Only incorporated, not mineralized, hydrocarbons were measured due to methodological problems. Several methods of using ${ }^{14} \mathrm{C}$-labelled hydrocarbons in a field situation are presented.
\end{abstract}

\section{INTRODUCTION}

An extensive body of literature documents the massive and catastrophic nature of oil spills in marine environments whereas the less dramatic problems of freshwater oil pollution have been overlooked by all but a few investigators (Caparello and LaRock, 1975; Ward and Brock, 1976). As a result, we know little about the effects of oil on freshwater biota or about oil biodegradation in freshwaters. Even less is known about the effects of oil in arctic freshwaters, a topic of immediate concern due to the construction of the trans-Alaska oil pipeline.

To examine the effects of oil on freshwater arctic biota, an experimental oil spill was carried out in July 1976 in a small lake (Oil Lake). A major aim of the microbial part of the study was to measure rates of in situ oil biodegradation, and to determine the effects of the oil on the normal heterotrophic microflora. Three methods were selected for testing: 1) total bacterial numbers in water and sediment based on direct counts with epifluorescence microscopy; 2) heterotrophic potential based on turnover times of ${ }^{14} \mathrm{C}$-glucose, and 3) hydrocarbon biodegradation based on uptake by bacteria of ${ }^{14} \mathrm{C}$-hexadecane and ${ }^{14} \mathrm{C}$-napthalene. Uptake of ${ }^{14} \mathrm{C}$-hydrocarbons has been used as an indicator of past oil exposure in marine waters by Walker and Colwell (1976), Seki (1976), Lee and Takahashi (1977), and Caparello and LaRock (1975), and in freshwaters by Caparello and LaRock (1975) and Ward and Brock (1976). Only Caparello and LaRock (1975) also worked with samples of sediment. We had difficulty with published methodologies for ${ }^{14} \mathrm{C}$-hydrocarbon metabolism and developed several new procedures as reported below. 


\section{METHODS}

The study area

Oil Lake is located $240 \mathrm{~km}$ south of Prudhoe Bay near the trans-Alaska oil pipeline. The lake has a maximum depth of $10 \mathrm{~m}$, and a maximum summer surface temperature of $20^{\circ} \mathrm{C}$. The water is oligotrophic; the sediments are flocculent, organic and iron-rich.

In July 1976, 2001 of Prudhoe Bay crude oil were added to a small section of Oil Lake $\left(816 \mathrm{~m}^{2}\right.$ in area and $4 \mathrm{~m}$ deep) enclosed by a sea-curtain. The rest of the lake was used as a control area. The microbial measurements were made in the summer of 1977.

\section{Bacteria counts}

Different boats and sets of oars, but the same samplers, were used in the control and oiled areas. Samples were taken in the control area first. Water samples were taken with a Van Dorn sampler, and preserved immediately with formaldehyde ( $6 \%$ final volume). Duplicate $2 \mathrm{ml}$ subsamples were stained for 1 min with $0.2 \mathrm{ml}$ of $0.1 \%$ acridine orange, filtered through $0.2 \mu \mathrm{m}$ Nuclepore filters dyed with Irgalan black, and the bacteria counted by epiflourescence microscopy at $1250 \times$ (Hobbie et al., 1977).

Triplicate sediment samples were taken with an Ekman grab sampler. The overlying water was drained off and sediment from the top $1 \mathrm{~cm}$ was removed and mixed. Duplicate $0.25 \mathrm{ml}$ subsamples were mixed with $100 \mathrm{ml}$ filtered lake water $(0.45 \mu \mathrm{m}$ pore millipore filters) at high speed in a Waring Blender for 3 min. A 1:10 dilution was prepared, from which $0.5 \mathrm{ml}$ subsamples were taken and then stained for $1 \mathrm{~min}$ with $1.5 \mathrm{ml}$ of $0.01 \%$ acridine orange and counted as above. Blanks of $2 \mathrm{ml}$ filtered lake water were also counted and blank counts were subtracted from sample counts. One milliliter subsamples of sediment were weighed, dried and reweighed to determine dry weight.

\section{Glucose uptake}

Duplicate $100 \mathrm{ml}$ water samples from each depth were placed in $250 \mathrm{ml}$ flasks. To each sample was added $10 \mu \mathrm{l}$ of ${ }^{14} \mathrm{C}$-glucose solution $(1 \mu \mathrm{Ci} / \mathrm{ml})$ containing $0.027 \mu \mathrm{g}$ glucose (final concentration $0.27 \mu \mathrm{g} / \mathrm{l}$ ). The flasks were stoppered with serum stoppers from each of which was suspended a plastic well (Kontes Glass Co., Vineland, N.J., No. K882320) containing a 2 X $5 \mathrm{~cm}$ pleated piece of Whatman No. 1 filter paper. Samples were incubated at in situ temperatures for 3 to 4 hours; two unpreserved blanks were harvested immediately (zero time incubation). Five $\mathrm{ml}$ of $2 \mathrm{~N} \mathrm{H}_{2} \mathrm{SO}_{4}$ was then injected into each water sample and $0.2 \mathrm{ml}$ of phenethylamine $\left(\mathrm{CO}_{2}\right.$ absorber) was injected onto each folded filter paper. Samples were incubated with gentle swirling for 1 hour. The filter papers were then removed and each placed in an empty, sealed glass scintillation vial for later counting in $10 \mathrm{ml}$ Bray's solution (New England Nuclear, Boston, MA). The particulates from the water samples were collected on $0.45 \mu \mathrm{m}$ pore size Millipore filters, rinsed with 20 $\mathrm{ml}$ filtered lake water, and placed in $10 \mathrm{ml}$ Bray's solution in liquid scintillation vials. Samples were counted by liquid scintillation using channels ratio quench correction. 
Glucose uptake by two of the three sediment samples collected for bacteria counts was also measured. A 1:100 (v/v) dilution of sediment was prepared and dispensed into vials in $2 \mathrm{ml}$ portions. Replicate sample vials and blanks were injected with ${ }^{14} \mathrm{C}$-glucose at each of four glucose concentrations (3 to $13.5 \mu \mathrm{g} / 1)$, and were stoppered, incubated and processed as described above. The recovery efficiency of $\mathrm{CO}_{2}$ was determined by following the above procedure with known amounts of ${ }^{14} \mathrm{C}-\mathrm{CO}_{2}$; it was $70 \%$ for water and $91 \%$ for sediment samples.

\section{Hydrocarbon assimilation}

Napthalene and hexadecane were purchased from Amersham-Searle Co., Arlington Heights, Illinois. The $\left(1-{ }^{14} \mathrm{C}\right)$ napthalene $(3.67 \mathrm{mCi} / \mathrm{mM})$ and $\mathrm{n}-\left(1-{ }^{14} \mathrm{C}\right)$ hexadecane $(54.4 \mathrm{mCi} / \mathrm{mM})$ were dissolved in $100 \%$ ethanol, $250 \mu \mathrm{Ci}$ per $10.0 \mathrm{ml}$. The hexadecane was supplied in benzene, which was removed by evaporation before the ethanol was added. The specific activity of the hexadecane was reduced to $18 \mathrm{mCi} / \mathrm{mM}$ by addition of unlabelled spectral grade hexadecane. The highest ethanol concentration in samples resulting from addition of the hydrocarbons was $0.5 \%$. At this concentration, ethanol had no effect on uptake of ${ }^{14} \mathrm{C}$-glucose by marine bacteria (Jordan, unpublished; Seki, 1976). We tried several different methodologies prior to the 1977 summer field season. The methods used in Alaska were still not entirely adequate and better techniques were subsequently developed in the laboratory at Woods Hole, as explained below.

One milliliter subsamples of the same three sediment samples that were collected for bacteria counts were each diluted with 99 or $49 \mathrm{ml}$ filtered lake water. Two milliliter subsamples were dispensed into glass liquid scintillation vials; three vials at each of two substrate levels per sample per hydrocarbon were prepared. An extra set was prepared and killed with formaldehyde (6\% final volume) to serve as blanks. The ethanol solution of ${ }^{14} \mathrm{C}$-hexadecane was dispensed with a $10 \mu$ l syringe to give theoretical initial sample concentrations of 800 and $1600 \mu \mathrm{g} / \mathrm{l}$. This procedure was repeated for napthalene to give substrate levels of 2150 and $4300 \mu \mathrm{g} / \mathrm{l}$. Each vial was immediately sealed with a foil-lined cap. Vials were incubated in trays sealed in plastic bags and floated for 4 to 11 days on the surface of a nearby lake. At the end of the incubation period, each vial was opened and immediately re-sealed with a rubber serum stopper from which was suspended a plastic well containing a pleated $2 \times 5 \mathrm{~cm}$ piece of Whatman No. 1 filter paper. Earlier tests showed losses of $\mathrm{CO}_{2}$ from the temporarily opened vials to be insignificant. The samples could not be incubated with the rubber stoppers in place since an average of $28 \%$ of the hexadecane and $96 \%$ of the napthalane were absorbed by the rubber after two days incubation. One tenth milliliter of $2 \mathrm{~N} \mathrm{H}_{2} \mathrm{SO}_{4}$ was then injected into each sample and $0.2 \mathrm{ml}$ of $2 \mathrm{~N} \mathrm{NaOH}$ was injected onto each filter paper to absorb released $\mathrm{CO}_{2}$. Phenethylamine could not be used since it also absorbed large amounts of the ${ }^{14} \mathrm{C}$-labelled hydrocarbons. The acidified samples were incubated with gentle swirling for one hour, by which time $69 \%$ of the ${ }^{14} \mathrm{C}-\mathrm{CO}_{2}$ in the samples had been absorbed by the $\mathrm{NaOH}$. 
Two hours of incubation would have increased the absorbtion to 78\%. Each filter paper was then placed in an empty glass scintillation vial, capped, and taken back to Woods Hole where $10 \mathrm{ml}$ Bray's solution was added. After waiting $24 \mathrm{hr}$ for the chemiluminescence caused by the $\mathrm{NaOH}$ to subside, the vials were counted by liquid scintillation.

The acidified samples were each filtered through $0.45 \mu \mathrm{m}$ pore size Millipore filters, rinsed with $1 \mathrm{ml}$ filtered lake water, and then rinsed with three $1 \mathrm{ml}$ portions of $95 \%$ ethanol. The ethanol was required to rinse out most of the hydrocarbons. In separate tests with ${ }^{14} \mathrm{C}$-glucose, ethanol rinsing caused a $14 \%$ loss of fixed ${ }^{14} \mathrm{C}$ so all filter counts were multiplied by 1.16 . The filters were placed in vials containing $10 \mathrm{ml}$ Bray's solution and were counted as above. Sediment particles on the filters caused a loss of counts due to self-absorption. This loss was measured by filtering triplicate $1 \mathrm{ml}$ subsamples of sediment diluted 1:100 which had been incubated with ${ }^{14} \mathrm{C}$-glucose, and also by filtering $1 \mathrm{ml}$ of the same ${ }^{14} \mathrm{C}$-labelled diluted sediment mixed with $2 \mathrm{ml}$ of unlabelled diluted sediment. The addition of the unlabelled sediment reduced the detectable counts by 30 to $50 \%$. All filter counts were multiplied by the appropriate correction factor (1.43 to 2.00).

Initial substrate levels in the samples were about $92 \%$ of the amount injected. The missing $8 \%$ presumably evaporated into the air space over the samples. Capped scintillation vials are not completely airtight and continual loss of hydrocarbons occurred during the incubations. After $251 \mathrm{hr}$ of incubation, an average of $26 \%$ of the napthalene and $37 \%$ of the hexadecane remained. In order to measure the amount of substrate remaining, several surplus formaldehyde killed samples had been prepared and incubated. To each of these sample vials, $15 \mathrm{ml}$ Aquasol was added and mixed for scintillation counting. Subsamples cannot be removed for counting ${ }^{14} \mathrm{C}$-hexadecane since the hydrocarbon is not homogeneously distributed in the aqueous samples.

The above filtration procedure was satisfactory for measuring incorporated hydrocarbons. Filter counts for blanks were 2600 - $9500 \mathrm{cpm}$ for hexadecane and $500-4000 \mathrm{cpm}$ for napthalene. Filter counts for blanks were $21-88 \%$ of sample counts for hexadecane, and $13-92 \%$ for napthalene.

The above procedure was not adequate for measuring mineralization because variable and large amounts of ${ }^{14} \mathrm{C}$-hydrocarbons were picked up on the $\mathrm{NaOH}$ treated filter papers along with the ${ }^{14} \mathrm{C}-\mathrm{CO}_{2}$. Some method of separating the residual hydrocarbons from evolved $\mathrm{CO}_{2}$ had to be used. During preliminary trials, drying the $\mathrm{NaOH}$-treated filter papers at room temperature had caused a loss of $53 \%$ of the hexadecane and $97 \%$ of the napthalene with negligible loss of ${ }^{14} \mathrm{C}-\mathrm{CO}_{3}=$. However, storage of the dry papers in empty vials while the samples were being shipped back to Woods Hole resulted in a nearly complete loss of the absorbed ${ }^{14} \mathrm{C}-\mathrm{CO}_{3}=$. The best method for measuring mineralization is to incubate samples in sealed, all-glass systems from which the gases may be flushed through a cold trap. The hydrocarbons are frozen out, and the $\mathrm{CO}_{2}$ passes through to be recovered (Beam and Perry, 1974). This system is expensive and required quantities of 
electric power and running water that were not available at the field site. Therefore, a variety of other inexpensive methods suitable for field use were subsequently tried in Woods Hole. Two successful methods are described below. The second method was preferred.

1) At the end of the incubation, each vial was opened and $0.2 \mathrm{ml} 2 \mathrm{~N} \mathrm{NaOH}$ immediately added to convert all $\mathrm{CO}^{2}$ to $\mathrm{CO}_{3}=$. The samples were then bubbled vigorously with air for $30 \mathrm{~min}$. This drove off about $50 \%$ of the hexadecane and $95 \%$ of the napthalene with no significant losses of $\mathrm{CO}_{2}$. The vials were then stoppered and the $\mathrm{CO}_{2}$ recovered as above.

2) The ${ }^{14} \mathrm{C}-\mathrm{CO}_{2}$ was recovered on $\mathrm{NaOH}$ soaked filter papers as first described, with no attempt to prevent hydrocarbon contamination of the papers. Each wet paper was then transferred to an empty vial which could be capped and stored for several days if necessary. Each vial was then stoppered with a rubber stopper from which was suspended a well containing a 2 x $5 \mathrm{~cm}$ piece of pleated Whatman No. 1 filter paper. One ml of $2 \mathrm{~N} \mathrm{H}_{2} \mathrm{SO}_{4}$ was injected onto the $\mathrm{NaOH}$ soaked paper at the bottom of the vial and the released $\mathrm{CO}_{2}$ was absorbed by $0.2 \mathrm{ml}$ of $2 \mathrm{~N} \mathrm{NaOH}$ injected on the paper in the well. After $2 \mathrm{hr}$ of incubation with gentle swirling, $100 \%$ of the $\mathrm{CO}_{2}$ was taken up by the paper in the well. Most of the hydrocarbon contaminating the first filter paper remained either in the $\mathrm{H}_{2} \mathrm{SO}_{4}$ or in the air space.

\section{RESULTS}

The number of bacteria per $\mathrm{ml}$ was greater in the oiled water than in the control water (Fig. 1), but differences were significant only in June. The number of bacteria per milliliter of sediment was not significantly different between the control and oiled areas (Table 1).

Turnover times for glucose in control and in oiled waters were not significantly different nor were monthly changes significant (Table 2). In the sediment, differences in glucose turnover times between replicates were significant and were as great or greater than any differences between control and oiled areas (Table 3).

Rates of uptake of hydrocarbons were highly variable and were affected by incubation time. Rates of hexadecane uptake by oiled sediments were significantly greater than uptake by control sediments only in the June $109 \mathrm{hr}$ incubation (Table 4). Rates of uptake of naphthalene by oiled sediments were significantly greater than uptake by control sediments only in the June $252 \mathrm{hr}$ incubation (Table 5). Rates of hexadecane uptake were usually higher than rates of naphthalene uptake. 


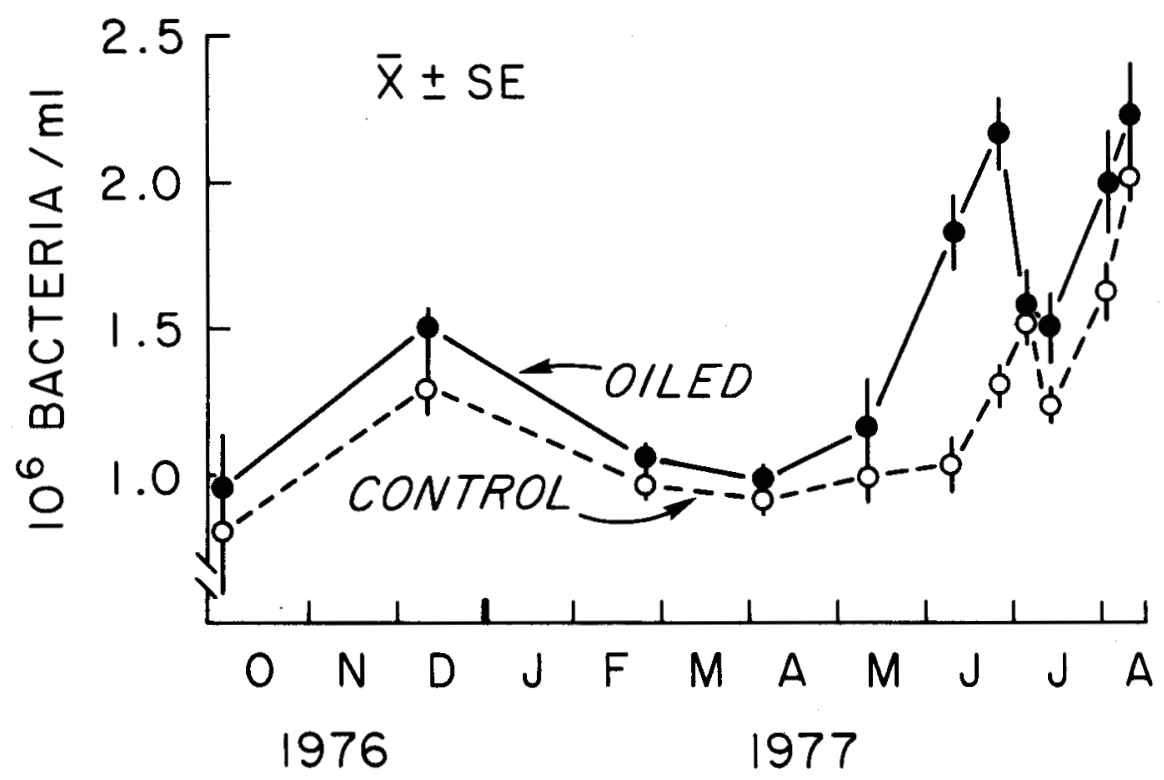

FIG. 1. Number of bacteria per milliliter in oiled and control waters of Oil Lake.

TABLE $1.10^{9}$ Bacteria $/ \mathrm{ml}$ sedimentary. Dry weight $/ \mathrm{ml}=0.26 \mathrm{~g}$

\begin{tabular}{lccc}
\hline & Control & Oiled & $95 \%$ LSD $^{\mathrm{a}}$ \\
\hline June 26 & 6.95 & 5.35 & 1.74 \\
July 5 & 5.36 & 4.83 & 1.53 \\
\hline
\end{tabular}

aLeast significant difference

TABLE 2. Mean turnover time (h) for glucose, 0-3 m depth in water

\begin{tabular}{llcc}
\hline & Control & Oiled & $95 \%$ LSD \\
\hline June 26 & 22.3 & 13.5 & $24.5^{\mathrm{a}}$ \\
July 4 & 30.8 & 27.0 & 24.5 \\
Aug. 3 & 38.2 & 20.3 & 24.5 \\
Aug. 11 & 22.0 & 25.0 & 24.5 \\
\hline $\mathrm{x}$ & 28.3 & 21.4 & $8.2^{\mathrm{b}}$ \\
\hline
\end{tabular}


TABLE 3. Mean turnover time (h) for glucose, $0-1 \mathrm{~cm}$ in sediment

\begin{tabular}{lccc}
\hline & Control & Oiled & 95\% LSD \\
\hline June 26 & 0.56 & 0.53 & 0.17 \\
& 0.24 & 0.62 & \\
July 6 & 0.49 & 0.45 & 0.16 \\
apooled, $\mathrm{N}=8$ & 0.30 & 1.5 &
\end{tabular}

TABLE 4 . Net uptake of hexadecane $(\mathrm{ng} / \mathrm{ml} / \mathrm{hr})$ by lake sediment. Substrate level $(\mu \mathrm{g} / \mathrm{ml}) \mathrm{A}=40, \mathrm{~B}=80, \mathrm{C}=160$.

\begin{tabular}{|c|c|c|c|c|c|c|c|c|c|c|c|c|}
\hline \multirow{4}{*}{$\begin{array}{l}\text { Incubation } \\
\text { time (hr) } \\
\text { Substrate level }\end{array}$} & \multicolumn{8}{|c|}{ June 27} & \multirow{2}{*}{\multicolumn{4}{|c|}{$\begin{array}{c}\text { July } 5 \\
138 \\
\end{array}$}} \\
\hline & \multicolumn{4}{|c|}{109} & \multicolumn{4}{|c|}{251} & & & & \\
\hline & \multicolumn{2}{|c|}{ Control } & \multicolumn{2}{|c|}{ Oiled } & \multicolumn{2}{|c|}{ Control } & \multicolumn{2}{|c|}{ Oiled } & \multicolumn{2}{|c|}{ Control } & \multicolumn{2}{|c|}{ Oiled } \\
\hline & B & $\mathrm{C}$ & B & $\mathrm{C}$ & $\mathrm{B}$ & $\mathrm{C}$ & $\mathrm{B}$ & $\mathrm{C}$ & $\mathrm{A}$ & $\mathrm{B}$ & A & B \\
\hline & $\overrightarrow{9.9}$ & $\overline{17}$ & $\overline{470}$ & $\overline{830}$ & $\overline{8.1}$ & $\overrightarrow{11}$ & 15 & $\overline{12}$ & $\overline{2.4}$ & $\overline{4.6}$ & $\overline{0.2}$ & $\overrightarrow{2.6}$ \\
\hline & 6.9 & 13 & 340 & 1000 & 11 & 16 & 46 & 9.8 & 1.2 & 5.9 & 0.0 & 0.4 \\
\hline & $\underline{2.0}$ & 8.2 & 160 & 360 & 2.7 & $\underline{55}$ & 4.4 & 8.4 & 3.4 & 11 & 1.7 & 3.7 \\
\hline $\mathrm{X}$ & $\overline{6.2^{\mathrm{a}}}$ & $13^{b}$ & $\overline{270^{a}}$ & $730^{b}$ & 7.4 & $\overline{11}$ & 7.9 & 10 & $\overline{2.3}$ & 7.1 & 0.6 & 2.2 \\
\hline \multicolumn{12}{|l|}{ pooled } & 0.8 \\
\hline
\end{tabular}

a Different at $10 \%$ probability level

${ }^{b}$ Different at $5 \%$ probability level

TABLE 5. Net uptake of napthalene $(\mathrm{ng} / \mathrm{ml} / \mathrm{hr})$ by lake sediment. Substrate level $(\mu \mathrm{g} / \mathrm{ml}) \mathrm{A}=107, \mathrm{~B}=215, \mathrm{C}=430$.

\begin{tabular}{|c|c|c|c|c|c|c|c|c|c|c|c|c|}
\hline \multirow{4}{*}{$\begin{array}{l}\begin{array}{l}\text { Incubation } \\
\text { time }(\mathrm{hr})\end{array} \\
\text { Substrate level }\end{array}$} & \multicolumn{8}{|c|}{ June 27} & \multirow{2}{*}{\multicolumn{4}{|c|}{$\begin{array}{c}\text { July } 5 \\
139\end{array}$}} \\
\hline & \multicolumn{4}{|c|}{110} & \multicolumn{4}{|c|}{252} & & & & \\
\hline & \multicolumn{2}{|c|}{ Control } & \multicolumn{2}{|c|}{ Oiled } & \multicolumn{2}{|c|}{ Control } & \multicolumn{2}{|c|}{ Oiled } & \multicolumn{2}{|c|}{ Control } & \multicolumn{2}{|c|}{ Oiled } \\
\hline & $\mathrm{B}$ & $\mathrm{C}$ & B & $\underline{\mathrm{C}}$ & B & $\bar{C}$ & B & $\mathrm{C}$ & $\bar{A}$ & B & A & B \\
\hline & 7.5 & 16 & 8.1 & 11 & 12 & 10 & 66 & 62 & 120 & 119 & 3.2 & 210 \\
\hline & 2.4 & 6.4 & 6.5 & 16 & 8.8 & 12 & 24 & 42 & 140 & 162 & 9.8 & 320 \\
\hline & 6.2 & 24 & 10 & 5 & 2.3 & 16 & 22 & 49 & 99 & 211 & 7.1 & 230 \\
\hline $\mathrm{x}$ & $\overline{5.4}$ & 16 & $\overline{8.3}$ & $\overline{11}$ & $7.7^{\mathrm{a}}$ & $\overline{13^{b}}$ & $\overline{37^{a}}$ & $\overline{51^{b}}$ & 120 & 164 & 6.7 & 250 \\
\hline $\begin{array}{l}\text { pooled } \\
\text { S.E. }(\mathrm{N}=3)\end{array}$ & & 8 & 2 & .4 & & 2.4 & & .0 & & .6 & 1.9 & 33.8 \\
\hline
\end{tabular}




\section{DISCUSSION}

After oil spills, hydrocarbon-utilizing bacteria commonly increase in numbers (Atlas and Bartha, 1973; Atlas et al., 1976; ZoBell, 1973). However, hydrocarbon utilizers usually represent less than $10 \%$ of the total heterotrophic bacterial population (Mulkins-Phillips and Stewart, 1974; Ward and Brock, 1976), so an increase in their numbers might not be noticeable as an increase in the total population. The significantly higher numbers of bacteria present in the oiled waters in June (Fig. 1) could be due to environmental differences created by the enclosing sea curtain. Numbers of several million bacteria per milliliter are common in both marine and freshwaters (Hobbie et al., 1977).

Little is known about the effect of oil on the metabolism of the normal heterotrophic microflora. Uptake by marine bacteria of ${ }^{14} \mathrm{C}$-glucose, a useful indicator of bacterial activity, was inhibited by $>300 \mathrm{ppb}$ No. 2 fuel oil or crude oil (Hodson et al., 1977). In other experiments, the effect of No. 2 fuel oil varied from inhibition to stimulation of glucose uptake by marine sediment bacteria (Jordan, unpublished). These experiments were short-term laboratory exposures of bacteria to oil, and may not reflect changes following chronic exposure in a field situation. The actual turnover times measured are similar to values reported for other freshwater lakes (Hall et al., 1972; Hobbie and Rublee 1977; Bergstein and Vestal 1978). The turnover times for sediment samples may be artificially high due to the stimulating effect of dilution and mixing (Hall et al. 1972), but relative comparisons should still be valid.

In waters chronically polluted with oil, an increased rate of hexadecane oxidation has been reported (Walker and Colwell 1976; Seki, 1976; Caparello and LaRock 1975). There have been few studies of the effect of a single oil spill on subsequent rates of hydrocarbon utilization. Three days after addition of a water extract of No. 2 fuel oil at $50 \mathrm{ppb}$ to CEPEX enclosures in Saanich Inlet, British Columbia, Lee and Takahashi (1975) measured increased degradation rates of heptadecane, naphthalene and methylnaphthalene, using ${ }^{14} \mathrm{C}$-hydrocarbons. A similar response was observed for marine sediments, using hexadecane and naphthalene (Jordan, unpublished). The minimum time following exposure and the minimum concentration of oil required to induce increased hydrocarbon utilization is not known. Also unknown is the length of time increased hydrocarbon utilization rates may persist following a single exposure to oil. Since hydrocarbons tend to accumulate and persist in sediments, the effects on sediment bacteria could be quite long-lasting especially in arctic environments where temperature is a limiting factor in oil degradation (Atlas and Bartha 1972). Our measurements were made nearly one year after the experimental oil spill.

The effect of incubation time on the measured rates of hydrocarbon uptake by Oil Lake sediment bacteria indicates that uptake rates were not constant throughout the incubation period. Uptake may have proceeded through lag, log and stationary phases, analogous to those in a batch culture, prior to the first harvesting. Ward and Brock (1976) reported a lag phase of at least $20 \mathrm{hr}$ when water from Lake Mendota was incubated with hexadecane. They 
believe that this lag phase could represent the time needed for the growth of the hydrocarbon-degrading population to measureable levels, or may represent the time needed for induction of hydrocarbon-degrading enzymes in a pre-existing population. The rate of the logarithmic uptake phase in the Oil Lake samples was more rapid than anticipated, and 20 to $68 \%$ of the hexadecane was incorporated by the oiled sediments and their bacteria within $109 \mathrm{hr}$. Most or all of the remaining 32 to $80 \%$ had probably been oxidized to $\mathrm{CO}_{2}$ which indicates attainment of the stationary phase. During the prolonged incubation in stationary phase, the bacteria presumably either respired most of the incorporated ${ }^{14} \mathrm{C}$, or lost most of the ${ }^{14} \mathrm{C}$ through lysis or leaching of soluble organics, or both. As a result, very little ${ }^{14} \mathrm{C}$ remained in particulate form in the samples harvested at 138 and $241 \mathrm{hr}$. Only more detailed time course measurements would have given the actual maximum uptake rates.

Different results were obtained with naphthalene, which is utilized less readily than alkanes such as hexadecane (Walker and Colwell 1976; Westlake et al. 1974). The greatest uptake rates occurred in the samples incubated for $138 \mathrm{hr}$ which showed a net fixation of up to $21 \%$ of the added naphthalene. An elevated rate of uptake by oiled sediments was measured in the samples incubated for $251 \mathrm{hr}$ but not $110 \mathrm{hr}$. Apparently there was a long initial lag period, when naphthalene uptake was zero or very low, during part or all of the first $110 \mathrm{hr}$. Bergstein and Vestal (1978) also reported initially low rates of naphthalene mineralization ( $0-10$ days' incubation) followed by much higher rates with increased incubation time (10-24 days).

Selection for hydrocarbon-degrading bacteria could be stimulated by the substrate levels added to incubated samples, independent of any past exposure to oil. The high naphthalene uptake rates measured for control sediment samples in July (Table 5) may be the result of such a selection process. Variation in unmeasured environmental factors such as temperature and concentrations of $\mathrm{N}$ and $\mathrm{P}$ in the lake water used for sediment dilution and the process of diluting and mixing the sediment samples could have affected hydrocarbon uptake rates.

Based on the data in Tables 4 and 5, it appears that exposure to Prudhoe Bay crude oil in 1976 probably did result in an increased hydrocarbon biodegradation potential in oiled Oil Lake sediments, an increase that persisted until 1977. The uptake rates reported in Tables 4 and 5 are similar to those found in organic marine sediments of Buzzards Bay, Mass. (Jordan, unpublished). We know of no published rates of hydrocarbon biodegradation in sediments of freshwater lakes except those of Caparello and LaRock (1975) which are expressed only as a percentage. If hexadecane and naphthalene were degraded at a rate of $100 \mu \mathrm{g} / \mathrm{ml} / \mathrm{hr}$ year-round, $0.88 \mathrm{~g} / \mathrm{ml}$ of each would be degraded annually. This is an unrealistically high amount, especially considering that these hydrocarbons are just two of many components of Prudhoe Bay crude oil. Actual in situ rates in sediments are difficult if not impossible to measure. As was found for the waters of Lake Mendota (Ward and Brock, 1976), hydrocarbon utilization in situ may be limited to the brief times of year when high enough temperatures occur simultaneously with 
adequate levels of $\mathrm{N}$ and $\mathrm{P}$. In sediments, lack of $\mathrm{O}_{2}$ may be another limiting factor.

In future studies, we recommend that microbial measurements be made before, during and immediately after the oil spill. We also recommend that a different type of control be used. Financial constraints prevented the purchase of more than one sea curtain to enclose the oiled area. It would be preferable to use two sea curtains, one to enclose the oiled area and the other the control, or even better, to select a lake that could be divided in half.

\section{ACKNOWLEDGEMENTS}

Oil spill logistics were handled by R. Barsdate and funded by E. P. A. grant no. R80415 2010. The microbial work was funded by ERDA under contract E(11-1)-2989 to the Marine Biological Laboratory.

\section{REFERENCES}

ATLAS, R. M. and R. BARTHA. 1972. Biodegradation of petroleum in seawater at low temperatures. Canadian Journal of Microbiology. 18:1851-1855.

- and 1973 . Abundance, distribution and oil degradation potential of microorganisms in Raritan Bay. Environmental Pollution. 4:291-300.

, E. A. SCHOFIELD, F. A. MORELLI, and R. E. CAMERON. 1976. Effects of petroleum pollutants on arctic microbial populations. Environmental Pollution. 10:35-43.

BEAM, H. W. and J. J. PERRY. 1974. Microbial degradation of cycloparaffinic hydrocarbons via co-metabolism and commensalism. Journal of General Microbiology. 82:163-169.

BERGSTEIN, P. E. and J. R. VESTAL. 1978. Crude oil biodegradation in arctic tundra ponds. Arctic (this volume).

CAPARELLO, D. M. and P. A. LAROCK. 1975. A radio-isotope assay for the quantification of hydrocarbon biodegradation potential in environmental samples. Microbial Ecology, 2:28-42.

HALL, K. J., P. M. KLIEBER and J. YESAKI. 1972. Heterotrophic uptake of organic solutes by microorganisms in the sediment. Memoire dell'Instituto Italiano di Idrobiologia. 29 Suppl.: 441-471.

HOBBIE, J. E., R. J. DALEY and S. JASPER. 1977. Use of Nuclepore filters for counting bacteria by fluorescence microscopy. Applied Environmental Microbiology. 33:1225-1228.

- and P. RUBLEE. 1977. Radioisotope studies of heterotrophic bacteria in aquatic ecosystems, $p$. 441-476. In J. Cairns, Jr. (ed.) Aquatic Microbial Communities. Garland Publishing, N.Y.

HODSON, R. E., F. AZAM and R. F. LEE. 1977. Effects of four oils on marine bacterial populations: controlled ecosystem pollution experiment. Bulletin of Marine Science. 27:119-126.

LEE, R. F. and M. TAKAHASHI. 1977. The fate and effect of petroleum in controlled ecosystem enclosures. Rapports et Proces-Verbaux des Reunions, Conseil International pour l'Exploration de la Mer. 171:150-156.

MULKINS-PHILLIPS, G. J. and J. E. STEWART. 1974. Distribution of hydrocarbon-utilizing bacteria in northwestern Atlantic waters and coastal sediments. Canadian Journal of Microbiology. 20:955-962.

SEKI, H. 1976. Method for estimating the decomposition of hexadecane in the marine environment. Applied Environmental Microbiology. 31:439-441.

WALKER, J. D. and R. R. COLWELL. 1976. Measuring the potential activity of hydrocarbon-degrading bacteria. Applied Environmental Microbiology. 31:189-197.

WARD, D. M. and T. D. BROCK. 1976. Environmental factors influencing the rate of hydrocarbon oxidation in temperate lakes. Applied Environmental Microbiology. 31:764-772.

WESTLAKE, D. W. S., A. JOBSON, R. PHILLIPPE, and F. D. COOK. 1974. Biodegradability and crude oil composition. Canadian Journal of Microbiology. 20:915-928.

ZOBELL. C. E. 1973. Microbial degradation of oil: present status, problems and perspectives. p. 1-16 In D. G. Ahern and S. P. Meyers (eds.) The Microbial Degradation of Oil Pollutants. Pub. No. LSU-SG-73-01, Louisiana State U., Baton Rouge. 